\title{
Analisis Pengaruh EPS, DPR, dan DER terhadap Harga Saham Sektor Trade, Services, \& Investment di BEI
}

\author{
Agustina N. Girsang \\ Universitas Prima Indonesia \\ novgirs96@gmail.com
}

\section{Holfian D. Tambun}

Universitas Prima Indonesia

\section{Ananda Putri}

Universitas Prima Indonesia

Anandaputrihilwana@gmail.com

\section{Debby Rarasati}

Universitas Prima Indonesia

debbyrarasati@gmail.com

\section{Derma S. S. Nainggolan}

Universitas Prima Indonesia

dermass96@gmail.com

\section{Putri Desi}

Universitas Prima Indonesia

putridesisusanti@gmail.com

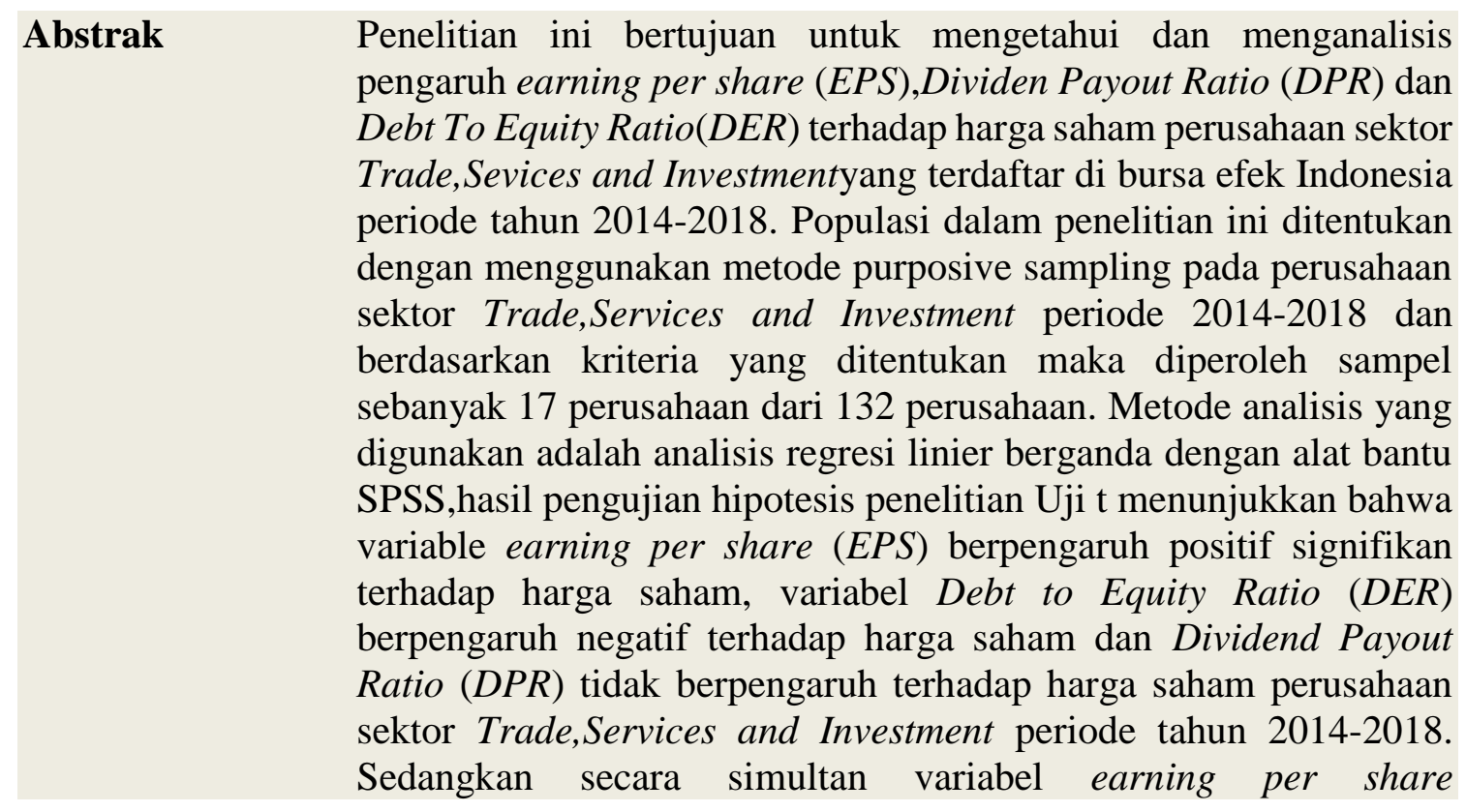


(EPS),Dividend Payout Ratio (DPR) dan Debt to Equity Ratio (DER) berpengaruh terhadap harga saham perusahaan sektor Trade,Services and Investment. Koefisien determinasi 53,6\% menunjukkan bahwa kemampuan variabel EPS,DPR dan DER dalam menjelaskan harga saham sebesar $53,6 \%$ dan sisanya $46,4 \%$ dijelaskan oleh variabel lain yang tidak diteliti pada penelitian ini

Kata Kunci $\quad$ Earning Per Share, Dividend Payout Ratio, Debt To Equity Ratio, Harga Saham

\section{PENDAHULUAN}

Pasar modal dapat diartikan sebagai suatu tempat yang mempertemukan pihak-pihak yang membutuhkan dana dengan pihak yang menyediakan dana (investor) yang juga merupakan alternatif penyaluran dana dari masyarakat ke perusahaan yang dapat berupa saham, obligasi dan sebagainya. Pendanaan tersebut dapat digunakan perusahaan untuk memperkuat dan menjaga kestabilan kondisi keuangan perusahaannya.

Saham dapat didefinisikan sebagai tanda pernyataan atau kepemilikan seseorang atau badan dalam suatu perusahaan atau perseroan terbatas. saham berwujud selembar kertas yang menerangkan bahwa pemilik kertas tersebut adalah pemilik perusahaan yang menerbitkan surat berharga tersebut. Darmadji\&Fakhruddin (2012:5).

Rasio keuangan dapat menjadi sumber informasi bagi para investor dalam menilai keberhasilan perusahaan dan menjadi pertimbangan untuk pengambilan keputusan pembelian saham. Rasio-rasio yang digunakan dalam penelitian ini adalah rasio profitabilitas dengan variabel Earning Per Share, Dividen Perusahaan dengan variabel Dividend Payout Ratio, dan rasio Solvabilitas dengan variabel Debt To Equity Ratio.

Tujuan dari penelitian ini adalah untuk menganalisis :

1. Pengaruh Earning Per Share (EPS) terhadap harga saham perusahaansektor Trade, Services, \& Investment yang terdaftar di Bursa Efek Indonesia .

2. PengaruhDividend Payout Ratio (DPR) terhadap harga saham perusahaan sektor Trade, Services, \& Investment yang terdaftar di Bursa Efek Indonesia .

3. Pengaruh Debt To Equity Ratio(DER) terhadap harga saham perusahaan sektor Trade, Services, \& Investment yang terdaftar di Bursa Efek Indonesia .

4. Pengaruh Earning Per Share (EPS), Dividend Payout Ratio (DPR) dan Debt to Equity Ratio (DER) terhadap harga saham perusahaan sektor Trade, Services, \& Investment yang terdaftar di Bursa Efek Indonesia .

\section{TINJAUAN PUSTAKA}

\subsection{Teori Saham}

Menurut Rodoni dan Ali (2014 : 52) Saham adalah salah satu sekuritas yang diperdagangkan di bursa efek. Saham didefinisikan sebagai penyertaan atau kepemilikan seseorang atau badan usaha dalam suatu perusahaan.Menurut Darmadji dan Fakhrudin (2012 : 5) Saham dapat didefinisikan sebagai tanda pernyataan atau kepemilikan seseorang atau badan dalam suatu perusahaan atau perseroan terbatas . saham berwujud selembar kertas yang menerangkan bahwa pemilik kertas tersebut adalah pemilik perusahaan yang menerbitkan surat berharga tersebut 
Berdasarkan beberapa pendapat diatas maka dapat disimpulkan bahwa saham merupakan tanda kepemilikan atau keikutsertaan investor terhadap perusahaan dengan menanamkanmodalnya keperusahaan.Harga saham Menurut Kodrat dan Indonanjaya (2010:13) , adalah harga penutupan atau close price. Sedangkan definisi harga saham Menurut Kodrat (2010 : 1) menyatakan bahwa Harga Saham merupakan harga yang terbentuk di bursa saham dan umumnya harga saham itu diperoleh untuk menghitung nilai saham .

\subsection{Teori Earning Per Share(EPS)}

Menurut Fahmi (2012:97) Earning Per Share atau laba per lembar saham adalah bentuk pemberian keuntungan yang diberikan kepada para pemegang saham dari setiap lembar saham yang dimiliki.

Menurut Tryfino (2009 : 11) Earning Per Share adalah ratio yang digunakan untuk menghitung laba / keuntungan bersih yang diperoleh dari selembar saham.

IndikatorEarning Per Share (EPS) adalah sebagai berikut :

(Darmadji\&Fakhruddin 2012:154)

$$
\text { Earning Per Share }=\frac{\text { Laba Bersih }}{\text { Jumlah Saham Beredar }} \text { rning Per Share }=\text { Laba }
$$

Bersih/Jumlah Saham Beredar

\subsection{Teori Dividend Payout Ratio (DPR)}

Menurut (Murhadi 2013:65) Dividen payout ratio merupakan rasio yang menggambarkan besarnya proporsi dividen yang dibagikan terhadap pendapatan bersih perusahaan.

Menurut Sudana (2011:26) menyatakan bahwa rasio ini mengukur berapa besar bagian laba bersih setelah pajak yang dibayarkan sebagai dividen kepada pemegang saham. semakin besar rasio ini berarti semakin sedikit bagian laba yang ditahan untuk membelanjai investasi yang dilakukan perusahaan

Menurut Sartono (2012:292-294) Faktor-faktor yang mempengaruhi Dividen Payout Ratio yaitu:

1. Kebutuhan Dana perusahaan

2. Likuiditas

3. Kemampuan Meminjam

4. Keadaan pemegang Saham

5. Stabilitas Dividen

Menurut Hani (2015:125) Indikator untuk menghitung Dividend Payout Ratio adalah:

$$
D P R=\frac{\text { Deviden }}{\text { Eat }} \mathrm{R}=\text { Deviden } / \text { Eat }
$$

\subsection{Teori Debt To Equity Ratio (DER)}

Menurut Syamsuddin (2013:54) Menyatakan bahwa rasio ini menunjukkan hubungan antara jumlah pinjaman jangka panjang yang diberikan oleh para kreditur dengan jumlah modal sendiri yang diberikan oleh pemilik perusahaan 
Menurut Kasmir (2012:158) Semakin besar ratio ini, akan semakin tidak menguntungkan karena akan semakin besar resiko yang ditanggung atas kegagalan yang mungkin terjadi di perusahaan. Sebaliknya dengan ratio yang rendah, semakin tinggi tingkat pendanaan yang disediakan pemilik dan semakin besar batas pengamanan bagi peminjam jika terjadi kerugian atau penyusutan terhadap nilai aktiva. adalah :

Menurut Hery 2015 :197 Indikator Untuk menghitung Debt To Equity Ratio M

$$
D E R=\frac{\text { Total Utang }}{\text { Modal }(\text { Equity })} \mathrm{R}=\text { Total Utang/Modal (Equity) }
$$

\subsection{Penelitian Terdahulu}

Tabel II.1 Penelitian Terdahulu

\begin{tabular}{|c|c|c|c|c|}
\hline No & $\begin{array}{l}\text { Peneliti } \\
\text { Terdahulu }\end{array}$ & Judul Penelitian & Variabel & Hasil Penelitian \\
\hline 1. & $\begin{array}{l}\text { Rescyana Putri } \\
\text { Utami (2012) }\end{array}$ & $\begin{array}{lr}\text { Pengaruh } & \text { Dividend } \\
\text { Per Share, } & \text { Return On } \\
\text { Equity dan } & \text { Net Profit } \\
\text { Margin } & \text { terhadap } \\
\text { Harga } & \text { Saham } \\
\text { Perusahaan } & \text { industry } \\
\text { manufaktur } & \text { yang } \\
\text { tercatat di } & \text { Bursa Efek } \\
\text { Indonesia } & \text { periode } \\
2006-2010 & \end{array}$ & $\begin{array}{l}\mathrm{Y}=\text { Harga } \\
\text { Saham } \\
X_{1}=\text { Dividend } \\
\text { Per Share } \\
X_{2}=\text { Return on } \\
\text { Equity } \\
X_{3}=\text { Net Profit } \\
\text { Margin }\end{array}$ & $\begin{array}{l}\text { Dividend Per Share, } \\
\text { Return On Equity dan } \\
\text { Net Profit Margin } \\
\text { memiliki pengaruh } \\
\text { positif dan signifikan } \\
\text { secara simultan dan } \\
\text { parsial terhadap Harga } \\
\text { Saham }\end{array}$ \\
\hline 2. & $\begin{array}{l}\text { Dwi Rahmawati } \\
\text { (2017) }\end{array}$ & $\begin{array}{l}\text { Pengaruh DPR, EPS, } \\
\text { dan DER Terhadap } \\
\text { Harga Saham }\end{array}$ & $\begin{array}{l}\mathrm{Y}=\text { Harga } \\
\text { Saham } \\
X_{1}=\mathrm{DPR} \\
X_{2}=\mathrm{EPS} \\
X_{3}=\mathrm{DER}\end{array}$ & $\begin{array}{l}\text { DPR , EPS, dan DER } \\
\text { berpengaruh positif dan } \\
\text { signifikan terhadap } \\
\text { harga saham }\end{array}$ \\
\hline 3. & $\begin{array}{lr}\text { Ni Made } & \text { Putri } \\
\text { Sri Rahayu dan I } \\
\text { Made } \quad \text { Dana } \\
(2016) & \end{array}$ & $\begin{array}{l}\text { Pengaruh EVA, MVA } \\
\text { dan Likuiditas } \\
\text { terhadap Harga Saham } \\
\text { Pada perusahaan Food } \\
\text { and Beverages }\end{array}$ & $\begin{array}{l}Y=\text { Harga } \\
\text { Saham } \\
X_{1}=\text { EVA } \\
X_{2}=\text { MVA } \\
X_{3}=\text { Likuiditas }\end{array}$ & $\begin{array}{lr}\text { EVA } & \text { berpengaruh } \\
\text { Negatif } & \text { signifikan } \\
\text { terhadap Harga Saham } & \\
\text { MVA dan } & \text { Likuiditas } \\
\text { berpengaruh } & \text { positif } \\
\text { signifikan } & \text { terhadap } \\
\text { harga saham }\end{array}$ \\
\hline 4. & $\begin{array}{l}\text { Rheza } \\
\text { Dewangga } \\
\text { Nugraha \& Budi } \\
\text { Sudaryanto }\end{array}$ & $\begin{array}{l}\text { Analisis pengaruh } \\
\text { DPR, DER, ROE dan } \\
\text { TATO terhadap harga } \\
\text { saham (studi kasus } \\
\text { pada perusahaan } \\
\text { industry dasar dan } \\
\text { kimia yang terdaftar di } \\
\text { BEI periode 2010- } \\
2014\end{array}$ & $\begin{array}{l}Y=\text { Harga } \\
\text { Saham } \\
X_{1}=\text { DPR } \\
X_{2}=\text { DER } \\
X_{3}=\text { DER } \\
X_{4}=\text { TATO }\end{array}$ & 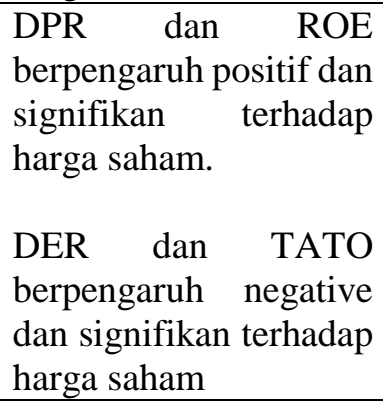 \\
\hline
\end{tabular}




\subsection{Teori Pengaruh Earning Per Share Terhadap Harga Saham}

Menurut Kodrat (2010: 283) mengatakan bahwa Hubungan antara harga saham seharusnya dengan (nilai intrinsik) dengan Earning Per Share adalah positif, yaitu semakin besar pendapatan perlembar saham, semakin besar harga dari saham..

\subsection{Teori Pengaruh Dividend Payout RatioTerhadap Harga Saham}

Menurut Sudana (2015:193) Berdasarkan kebijakan Bird in-the hand theory, kebijakan dividen berpengaruh positif terhadap harga pasar saham. artinya jika dividen yang dibagikan perusahaan semakin besar, maka harga pasar saham perusahaan tersebut akan semakin tinggi dan sebaliknya

\section{Teori Pengaruh Debt To Equity Ratio Terhadap Harga Saham}

Menurut Sartono (2015:232), Harga Saham perusahaan yang tidak memiliki utang akan meningkat sementara harga saham yang memiliki utang akan turun.

\section{Kerangka Konseptual}

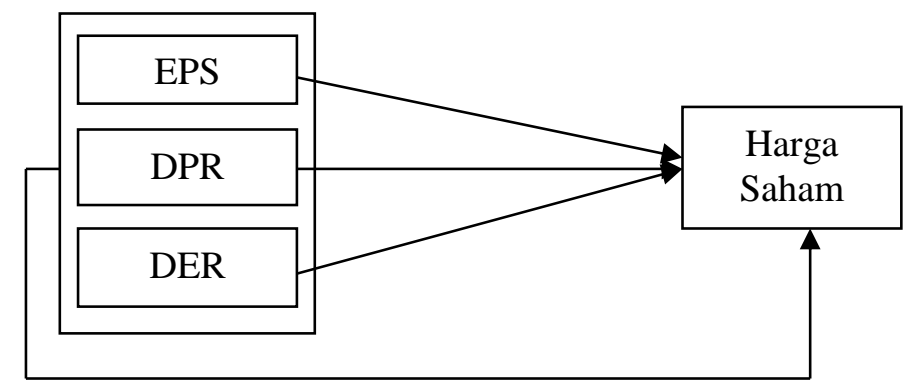

Gambar II.1. Kerangka Konseptual

\section{METODE PENELITIAN}

Dalam penelitian ini menggunakan pendekatan penelitian kuantitatif yang merupakan penelitian untuk mengetahui pengaruh atau hubungan antara variabel bebas dengan variabel terikatnya. Populasi yang akan digunakan dalam penelitian ini adalah semua perusahaan pada sektor Trade, Services, \& Investment yang terdaftar di Bursa Efek Indonesia periode 2014-2018yang berjumlah 17 perusahaan. Teknik pengambilan sampel menggunakan teknik purposive sampling yaitu teknik pengambilan sampel dengan menggunakan kriteria.

Teknik pengumpulan data dalam penelitian ini menggunakan studi dokumentasi yaitu mengumpulkan data yang telah ada dalam bentuk Laporan Keuangan, dari Bursa Efek Indonesia periode tahun 2014 sampai dengan tahun 2018 yang diperoleh peneliti secara tidak langsung melalui media perantara internet diambil langsung dari situs Bursa Efek Indonesia (www.idx.co.id).

Penelitian ini menggunakan model regresi linier berganda. Model analisis ini digunakan dengan suatu alasan untuk melihat ada tidaknya pengaruh beberapa variabel bebas terhadap variabel tidak bebas, baik secara simultan (bersama-sama) maupun secara 
parsial (masing-masing). Berdasarkan itu semua, maka spesifikasi model yang digunakan dalam penelitian ini adalah :

Dimana :

$$
\text { Ln_HS }=\mathbf{a}+\beta 1 E P S+\beta 2 D P R+\beta 3 D E R+e
$$

$\begin{array}{ll}\text { Ln_HS } & =\text { Harga Saham } \\ \mathrm{X}_{1} & =\text { Earning Per Share } \\ \mathrm{X}_{2} & =\text { Dividend Payout Ratio } \\ \mathrm{X}_{3} & =\text { Debt To Equity Ratio } \\ \beta 0, \beta 1, \beta 2, \beta 3 & =\text { koefesien regresi } \\ \mathrm{a} & =\text { konstanta } \\ \mathrm{e} & =\text { standart error }\end{array}$

Tahapan pengujian yang dilakukan dalam penelitian ini meliputi :

1. Statistik Deskriptif

2. Uji Asumsi Klasik

- Uji Normalitas

Pengujian secara uji normalitas melalui uji statistik non-parametik kolmogrov-smirnov (Ghozali, 2013:156)

- Uji Multikolinieritas

Pengujian secara uji multikolinieritas dengan melihat nilai Tolanrance dan VIF. (Ghozali, 2013:103)

- Uji Autokorelasi

Pengujian dengan uji autokolerasi menggunakan uji Run Test. (Ghozali, 2013:107)

- Uji Heteroskedastisitas

Pengujian dengan uji heterokedastisitas dengan menggunakan uji

Spearman's Rho. (Priyatno, 2017:108)

3. Uji Hipotesis

- Uji Koefisien Determinasi $\left(\mathrm{R}^{2}\right)$

Mengukur seberapa jauh kemampuan model dalam menerangkan variasi variabel dependent. (Ghozali, 2013:95)

- Secara Individu (Parsial)

Untuk mengetahui signifikan tidaknya pengaruh dari masingmasingvariabel bebas terhadap variabel terikat. (Sanusi, 2014:138)

- Secara Serentak (Simultan)

Menunjukan bahwa variasi variabel terikat dijelaskan sekian persen oleh variabel bebas secara bersama-sama adalah benar-benar nyata dan bukan terjadi secara kebetulan. (Sanusi, 2014:137)

\section{ANALISIS \& PEMBAHASAN}

\subsection{Statistik Deskriptif}

Analisis ini bertujuan untuk mengetahui tren nilai terendah (minimum), nilai tertinggi (maksimum), nilai rata-rata (mean), dan standar deviasinya sehingga penulis dapat mendeskriptifkan hasil penelitian yang berupa angka-angka kedalam analisis. Berikut ini ditampilkan data statistik secara umum dari seluruh data yang digunakan : 
Tabel 4.1. Statistik Deskriptif

Descriptive Statistics

\begin{tabular}{|l|r|r|r|r|r|}
\hline & $\mathrm{N}$ & Minimum & Maximum & \multicolumn{1}{c|}{ Mean } & \multicolumn{1}{c|}{ Std. Deviation } \\
\hline EPS & 85 &, 9637 & 692,1733 & 104,182295 & 133,4393823 \\
DPR & 85 &, 0344 & 2,8056 &, 388781 &, 4252855 \\
DER & 85 &, 0751 & 940,7371 & 18,888485 & 117,9411884 \\
LN_HS & 85 & 3,95 & 9,78 & 6,6534 & 1,12199 \\
Valid N (listwise) & 85 & & & & \\
\hline
\end{tabular}

Sumber : hasil output SPSS 23, 2019

Dari tabel tersebut, dapat dijelaskan bahwa rata-rata EPS adalah 104,1823 dengan standar deviasi 133,4393823. Nilai maksimum adalah 692,1733 dan nilai terendah adalah 0,9636. Hal ini dapat diindikasikan bahwa data bervariatif dan menyebar diantara nilai maksimum dan nilai minimum. Rata-rata DPR adalah 0,388781 dengan standar deviasi 0,4252855 . Nilai maksimum adalah 2,8056 dan nilai minimum 0,0344. Hal ini dapat diindikasikan bahwa data bervariatif dan menyebar diantara nilai maksimum dan nilai minimum. Rata-rata DER adalah 1,888849 dengan standar deviasi 117,9411884. Nilai maksimum adalah 940,7371 dan nilai minimum 0,0751. Hal ini dapat diindikasikan bahwa data bervariatif dan menyebar diantara nilai maksimum dan nilai minimum. Ratarata harga saham adalah 6,6534 dengan sstandar deviasi 1,12199. Nilai maksimum adalah 978 dan nilai minimum 3,95. Hal ini dapat diindikasikan bahwa data bervariatif dan menyebar diantara nilai maksimum dan nilai minimum. Jumlah sampel adalah sebanyak 85 yang diperoleh dari 17 perusahaan dari tahun $2014-2018$.

\subsection{Hasil Uji Normalitas}

Untuk mengetahui ada data yang dimiliki normal atau tidak, dapat digunakan digunakan uji statistik Kolmogrov-smirnov (K-S). Hasil dari uji normalitas dengan menggunakan terst Kolmogrov-smirnov (K-S) adalah seperti yang terlihat pada tabel berikut :

Tabel 4.2. Hasil Uji Normalitas One-Sample Kolmogorov-Smirnov Test

\begin{tabular}{|ll|r|}
\hline & & $\begin{array}{c}\text { Unstandardized } \\
\text { Residual }\end{array}$ \\
\hline N & Mean & 85 \\
Normal Parameters & \\
& Std. Deviation & .0000000 \\
Most Extreme Differences & Absolute & .75031994 \\
& Positive & .073 \\
& Negative & .051 \\
Kolmogorov-Smirnov Z & & -.073 \\
Asymp. Sig. (2-tailed) & & .669 \\
a. Test distribution is Normal. & .762 \\
\hline
\end{tabular}

Sumber : hasil output SPSS 23, 2019

Berdasarkan tabel 2 diatas diketahui bahwa semua variabel EPS, DPR, DER, dan Harga Saham berdistribusi normal karna nilai signifikansi 0,762 > 0,05. 


\subsection{Hasil Uji Multikolinieritas}

Pengujian ini bermaksud untuk menguji apakah pada model regresi ditemukan adanya kolerasi antar variabel bebas. Jika terjadi kolerasi, maka dinamakan terdapat problem multikolinieritas. Hasil dari uji multikolinieritas dapat dilihat dari tabel berikut :

Tabel 4.3. Hasil Uji Multikolinieritas

Coefficients $^{a}$

\begin{tabular}{|ll|r|r|}
\hline \multirow{2}{*}{ Model } & \multicolumn{2}{|c|}{ Collinearity Statistics } \\
\cline { 3 - 4 } & & Tolerance & \multicolumn{1}{c|}{ VIF } \\
\hline 1 & (Constant) & & \\
& EPS &, 993 & 1,007 \\
& DPR &, 990 & 1,010 \\
& DER &, 992 & 1,008 \\
\hline
\end{tabular}

Sumber : hasil output SPSS 23, 2019

\section{a. Dependent Variable: LN_HS}

Berdasarkan hasil pengujian diatas, dapat dilihat bahwa angka tolerance dari masing-masing variabel > 0,10 dan nilai VIF (Variace Inflation Factor) < 10, maka dapat disimpulkan tidak ada multikolinieritas antar variabel independen tersebut.

\subsection{Hasil Uji Autokolerasi}

Salah satu cara mendeteksi ada tidaknya gejala autokolreasi adalah dengan Run Test. Run Test digunakan untuk melihat apakah data residual terjadi secara random atau tidak. Hasil uji autokolerasi dapat dilihat dari tabel berikut :

Tabel 4.4. Hasil Uji Autokolerasi

\begin{tabular}{|l|r|}
\hline \multicolumn{2}{|c|}{ Runs Test } \\
\hline \multicolumn{1}{|c|}{$\begin{array}{c}\text { Unstandardized } \\
\text { Residual }\end{array}$} \\
\hline Test Value ${ }^{\mathrm{a}}$ & -.00716 \\
Cases < Test Value & 42 \\
Cases >= Test Value & 43 \\
Total Cases & 85 \\
Number of Runs & 49 \\
Z & 1.202 \\
Asymp. Sig. (2-tailed) & .229 \\
\hline
\end{tabular}

Sumber : hasil output SPSS 23, 2019

Hasil pengujian pada tabel diatas menunjukan nilai signifikansi Run Test sebesar 0.229 atau > 0,05 maka dapat disimpulkan bahwa residual random atau tidak terjadi autokolersi antar nilai residual.

\subsection{Hasil Uji Heterokedastisitas}

Uji Spearman's Rho bertujuan untuk mengkolerasikan variabel independen dengan residualnya. Hasil dari uji heterokedastisitas dapat ditunjukan dalam tabel Spearman's Rho : 
Tabel 4.5. Hasil Uji Spearmasn's Rho

\section{Correlations}

\begin{tabular}{|c|c|c|c|c|c|c|}
\hline & & & EPS & DPR & DER & $\begin{array}{l}\text { Unstandardize } \\
\text { d Residual }\end{array}$ \\
\hline \multirow[t]{12}{*}{ Spearman's rho } & \multirow[t]{3}{*}{ EPS } & $\begin{array}{l}\text { Correlation } \\
\text { Coefficient }\end{array}$ & 1,000 &,- 065 & 218* & 170 \\
\hline & & Sig. (2-tailed) & & ,554 & ,045 & 119 \\
\hline & & $\mathrm{N}$ & 85 & 85 & 85 & 85 \\
\hline & \multirow[t]{3}{*}{ DPR } & $\begin{array}{l}\text { Correlation } \\
\text { Coefficient }\end{array}$ &,- 065 & 1,000 &,$- 231^{*}$ & , 168 \\
\hline & & Sig. (2-tailed) & ,554 & & ,033 & 124 \\
\hline & & $\mathrm{N}$ & 85 & 85 & 85 & 85 \\
\hline & \multirow[t]{3}{*}{ DER } & $\begin{array}{l}\text { Correlation } \\
\text { Coefficient }\end{array}$ &, $218^{*}$ &,$- 231^{*}$ & 1,000 &,- 166 \\
\hline & & Sig. (2-tailed) &, 045 & ,033 & & , 128 \\
\hline & & $\mathrm{N}$ & 85 & 85 & 85 & 85 \\
\hline & \multirow[t]{3}{*}{ Unstandardized Residual } & $\begin{array}{l}\text { Correlation } \\
\text { Coefficient }\end{array}$ & , 170 & , 168 &,- 166 & \multirow[t]{3}{*}{1,000} \\
\hline & & Sig. (2-tailed) & (119 & 124 & 128 & \\
\hline & & $\mathrm{N}$ & 85 & 85 & 85 & \\
\hline
\end{tabular}

*. Correlation is significant at the 0.05 level (2-tailed).

Sumber : hasil output SPSS 23, 2019

Berdasarkan uji spearman's rho pada tabel diatas terlihat bahwa nilai signifikansi EPS sebesar 0,119>0,05, DPR sebesar 0,124 > 0,05 dan DER sebesar 0,128 >0,05. Hal ini menunjukan bahwa model regresi tidak terjadi gejala heterokedastisitas karena nilai signifikansinya diatas nilai $\alpha$ atau 0.05 .

\subsection{Model Analisis Regresi Linear Berganda}

Berdasarkan hasil regresi berganda, maka diperoleh model penelitian sebagai berikut :

$$
\text { LN_HS = 6.023 + 0,006EPS + 0,134DPR- 0,002DER }
$$

1. Nilai a sebesar 6.023artinya jika variabel EPS, DPR dan DERkonstan (tetap) maka harga saham (Y) adalah sebesar 6.023.

2. Nilai $\beta_{1}$ sebesar 0,006artinya setiap peningkatan EPS 1 satuan maka akan meningkatkanharga saham sebesar 0,006 satuan.

3. Nilai $\beta_{2}$ sebesar 0,134 artinya setiap peningkatanDPR1 satuan maka akan meningkatkan harga saham sebesar 0,134 satuan.

4. Nilai $\beta_{3}$ sebesar $-0,002$ artinya setiap peningkatan DER 1 satuan maka akan menurunkan harga saham sebesar 0,002 satuan.

\subsection{Pengujian Hipotesis}

\section{Hasil Uji Koefesien Determinasi}

Nilai koefesien determinasi (R2) dipergunakan untuk mengukur besarnya pengaruh variabel bebas dari EPS, DPR dan DER dengan harga saham pada perusahaan sektor Trade, Services and Investment yang terdaftar di Bursa Efek Indonesia. 
Tabel 4.6. Hasil Koefisien Determinasi

Model Summary ${ }^{b}$

\begin{tabular}{|l|r|r|r|r|r|}
\hline Model & $\mathrm{R}$ & $\mathrm{R}$ Square & $\begin{array}{c}\text { Adjusted R } \\
\text { Square }\end{array}$ & $\begin{array}{c}\text { Std. Error of the } \\
\text { Estimate }\end{array}$ & Durbin-Watson \\
\hline 1 &, $743^{\mathrm{a}}$ &, 553 &, 536 &, 76409 & 2,280 \\
\hline
\end{tabular}

a. Predictors: (Constant), DER, EPS, DPR

b. Dependent Variable: LN_HS

Sumber : hasil output SPSS 23, 2019

diperoleh nilai Adjusted $R$ Square $\left(\mathrm{R}^{2}\right)$ adalah 0,536 atau sama dengan 53,6\%. Hal ini menunjukkan bahwa kemampuan EPS, DPR, dan DER dalam menjelaskan Harga Saham sebesar 53,6\% dan sisanya 46,4\% dijelaskan oleh variabel lain.

\section{Hasil Uji Secara Parsial (Uji-t)}

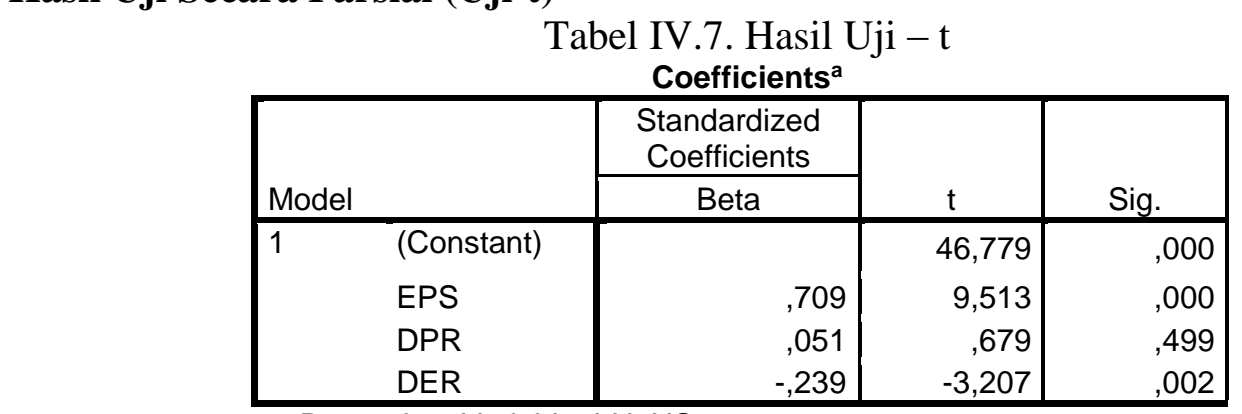

Sumber : hasil output SPSS 23, 2019

Berdasarkan hasil pengujian hipotesis pengaruh EPS terhadap harga saham diperolehnilai thitung $(9,513)$ lebih besar dari tabel $(1,989)$ dengan signifikansi 0,000 (Sig.> 0,05) maka Ho ditolak dan Ha diterima. Artinya secara parsial EPS berpengaruh positif dan signifikanterhadap harga saham pada perusahaan sektor Trade, Services, \& Investment yang terdaftar di Bursa Efek Indonesia.

Berdasarkan hasil pengujian hipotesis pengaruh DPR terhadap harga sahamdiperolehnilai thitung $(0,679)$ lebih besar dari tabel $(1,989)$ dengan signifikansi 0,499 (Sig. < 0,05) maka Ho diterima dan Ha ditolak. Artinya secara parsial DPR tidak berpengaruh terhadap hargasaham pada perusahaan sektor Trade, Services, \& Investment yang terdaftar di Bursa Efek Indonesia.

Berdasarkan hasil pengujian hipotesis pengaruh DER terhadap harga saham diperolehnilai thitung $(3,207)$ lebih besar dari tabel $(1,989)$ dengan signifikansi 0,002 (Sig.< 0,05) maka Ho ditolak dan Ha diterima. Artinya secara parsial DER berpengaruh positif dan signifikan terhadap hargasaham pada perusahaan sektor Trade, Services, \& Investment yang terdaftar di Bursa Efek Indonesia.

\section{Hasil Uji Simultan (Uji F)}

Pengujian secara simultan bertujuan untuk mengetahui ada tidaknya pengaruh variabel bebas secara bersama-sama dengan variabel terikat. Hasil pengujian secara simultan dapat dilihat sebagai berikut : 
Tabel 4.8. Hasil Uji - $\mathrm{f}$

ANOVAa

\begin{tabular}{|ll|r|r|r|r|r|}
\hline Model & & Sum of Squares & df & Mean Square & F & Sig. \\
\hline 1 & Regression & 58,454 & 3 & 19,485 & 33,374 &, $000^{\mathrm{b}}$ \\
& Residual & 47,290 & 81 &, 584 & & \\
& Total & 105,744 & 84 & & & \\
\hline
\end{tabular}

a. Dependent Variable: LN_HS

b. Predictors: (Constant), DER, EPS, DPR

Sumber : hasil output SPSS 23, 2019

Berdasarkan hasil pengujian hipotesis pengaruh efesiensi operasional EPS, DPR dan DER terhadap Harga Saham diperoleh nilai $F_{\text {hitung }}(33,374)$ lebih besar dari Ftabel $(2,717)$ dengan signifikansi 0,000 (Sig. $<0,05)$ maka Ha diterima. Artinya secara simultan EPS,DPR dan DER berpengaruh signifikan terhadap Harga Saham pada perusahaan sektor Trade, Services, \& Investment yang terdaftar di Bursa Efek Indonesia periode tahun 2014-2018.

\section{V.}

\section{Kesimpulan}

1. Hasil pengujian secara parsial membuktikan bahwa variabel DPR tidak berpengaruh signifikan terhadap harga saham. Hal ini dapat dilihat dari hasil pengujian hipotesis yang nilai signifikansinya lebih besar dari 0,05 yang berarti hipotesis ditolak.

2. Hasil pengujian secara parsial membuktikan bahwa variabel EPS berpengaruh positif dan signifikan terhadap harga saham. Hal ini dapat dilihat dari hasil pengujian hipotesis yang nilai signifikansinya lebih kecil dari 0,05 yang berarti hipotesis diterima.

3. Hasil pengujian secara parsial membuktikan bahwa variabel DER berpengaruh negative dan signifikan terhadap harga saham. Hal ini dapat dilihat dari hasil pengujian hipotesis yang nilai signifikansinya lebih besar dari 0,05 yang berarti hipotesis diterima.

4. Hasil penelitian ini juga membuktikan bahwa EPS,DPR dan DER secara bersamasama berpengaruh signifikan terhadap harga saham karena mempunyai tingkat signifikansi lebih kecil dari 0,05 (5\%), yang berarti hipotesis diterima.

\section{DAFTAR PUSTAKA}

Ambarwati, Sri Dwi Ari. 2010. Manajemen Keuangan Lanjut. Cetakan 1, Graha Ilmu. Darmadji, dkk. 2011. Pasar Modal Indonesia, Edisi 3, Salemba Empat, Jakarta.

DewanggaNugraha, Budi Sudaryanto. 2016. AnalisisPengaruh DPR,DER,ROEdan TATO TerhadapHargaSaham (StudiKasuspada Perusahaan Industry Dasardan Kimia yang terdaftar di BEI Periode 2010-2014).

DwiRahmawati. 2017. Pengaruh DPR, EPS, dan DER TerhadapHargaSaham.

Ghozali, I. 2016. Aplikasi Analisis Multivariate dengan Program Ibm Spss 23.Semarang: Badan Penerbit Universitas Diponegoro.

Gumanti, Ari Tatang. 2013. Kebijakan Dividen Teori, Empiris, dan Implikasi. Ed.1, UPP STIM YKPN. 
Hani, Syafrida. 2015. TeknikAnalisaLaporanKeuangan. UMSU Press.

Harahap, Sofyan Syafri. 2013. Analisis Kritis atas Laporan Keuangan. Cetakan 11, PT RajaGrafindo Persada.

Hery. 2015. Analisis Laporan Keuangan. Ed. 1. Cetakan Ketiga. Jakarta: Bumi Aksara. Kodrat dan Indonanjaya . 2010. Manajemen Investasi: Pendekatan Teknikal Analisis Saham. Yogyakarta: Gaha Ilmu.

Lukman,Syamsuddin. 2013. ManajemenKeuangan Perusahaan. Cetakan 12, PT RajaGrafindoPersada.

Ni Made Putri Sri Rahayu, I Made Dana. 2016. Pengaruh EVA, MVA danLikuiditasTerhadapHargaSahamPada Perusahaan Food and Beverages.

Priyatno,Duwi. 2017. Spss 22 Pengolah Data Terpraktis.

RescyanaPutriUtami. 2012. Pengaruh Dividend Per Share, Return On Equity dan Net Profit Margin TerhadapHargaSaham Perusahaan Industry Manufaktur yang tercatat di Bursa Efek Indonesia Periode 2006-2010.

Rodoni, Ahmad. 2014. ManajemenKeuangan Modern. Jakarta: MitraWacana Media.

Sanusi, Anwar. 2014. Metodologi Penelitian Bisnis. Cetakan Ke Empat. Jakarta : Salemba Empat.

Sartono, Agus. 2012. Manajemen Keuangan Teori dan Aplikasi. Ed.4, BPFEYogyakarta.

Sitanggang, J.P. 2013. ManajemenKeuangan Perusahaan Lanjutan. Ed, Jakarta: MitraWicana Media.

Soewadji, Jusuf MA.2012. PengantarMetodologiPenelitian. Jakarta: Penerbit Mitra Wicana Media.

Sudana, I Made. 2011. Manajemen Keuangan Perusahaan Teori da nPraktik.Erlangga: PT Gelora Aksara Pratama.

Sugiyono, P. D.2016. Metode Penelitian Kuantitatif ,Kualitatif, dan $R$ \& D. Bandung: Alfabeta.

Sunyoto, Danang. 2013. Analisis Laporan Keuangan untuk Bisnis. Jakarta: CAPS.

Tryfino. 2009. Cara Cerdas Berinvestasi Saham. Jakarta: Transmedia Pustaka.

Sumber Data:

$\underline{\text { www.idx.co.id }}$ 